\title{
Scientific Approach in Physical Education: Improving Creativity and Physical Fitness of Senior High School Students in Mountainous Areas
}

\author{
Beltasar Tarigan \\ Faculty of Sport and Health Education, Universitas Pendidikan Indonesia, Bandung, Indonesia \\ Received April 23, 2021; Revised July 14, 2021; Accepted July 20, 2021
}

\section{Cite This Paper in the following Citation Styles}

(a): [1] Beltasar Tarigan, "Scientific Approach in Physical Education: Improving Creativity and Physical Fitness of Senior High School Students in Mountainous Areas," International Journal of Human Movement and Sports Sciences, Vol. 9, No. 4A, pp. 77 - 81, 2021. DOI: 10.13189/saj.2021.091313.

(b): Beltasar Tarigan (2021). Scientific Approach in Physical Education: Improving Creativity and Physical Fitness of Senior High School Students in Mountainous Areas. International Journal of Human Movement and Sports Sciences, 9(4A), 77 - 81. DOI: 10.13189/saj.2021.091313.

Copyright $\odot 2021$ by authors, all rights reserved. Authors agree that this article remains permanently open access under the terms of the Creative Commons Attribution License 4.0 International License

\begin{abstract}
Background: This paper discusses the scientific approach in Physical Education. Physical Education emphasizes personal or body fitness. It promotes healthy living by exercising the body. Purpose: This study was aimed at analyzing the influence of the Physical Education approach to the creativity and physical fitness of high school students in mountainous areas. Methods: The method used was an experiment with pretest and post-test designs. The populations of this study were students of Lembang Public Senior High School 1, consisting of 2 groups. 36 students were taken as samples through simple random sampling technique. The instruments used were creativity tests and physical fitness tests. The data were processed using independent t-test statistical analysis with a confidence level of 0.05 . Results: The independent t-test calculation results, both the student's creativity and physical fitness components, showed a significant effect. Conclusion: The scientific approach in Physical Education carried out 3 times a week can increase the creativity and physical fitness of high school students living in mountainous areas. Meanwhile, if it is only done once a week, the results will be lower.
\end{abstract}

Keywords Physical Education, Scientific Approach, Creativity, Physical Fitness

\section{Introduction}

School is a formal education where students are educated. Their abilities must be nurtured and prepared. Their potential should be developed, thus they have personal qualities, a healthy body and soul, as well as an independent temperament and character. The educational process, including Physical Education and Sports, is an effort to support the achievement of national education goals. Physical Education is an inseparable part of the education system. Physical Education in the $20^{\text {th }}$ century places more emphasis on physical fitness, motor skills, and social knowledge [1,2]. The problem that occurs in the field is that the learning process is less attractive which causes Physical Education students to be less enthusiastic about carrying out a movement activity, so that the student physical fitness level is low. This strengthens the nation that the old (conventional) curriculum is implemented statically and rigidly by those who apply it in the field [3-5]. Other data show that the prevalence of attending Physical Education (PE) classes had decreased from $31.5 \%$ in 2011 to $29.4 \%$ in 2013 [6]. Meanwhile, the trend of activist research that affects physical and all components of physical fitness, including body composition, cardiorespiratory, muscle strength, and flexibility HRQOL or Health Related Quality of Life in children, gets less attention than adults [7,8]. Physical Education that is implemented properly is proven to 
improve physical fitness and have a positive impact, in general, including improving the quality of life [9]. Until now, there are still many Physical Education teachers who do not understand and master the learning models that can be used in learning, even still using conventional approaches in learning. The lack of the teacher's ability to develop learning models can have various negative impacts, including learning becoming less attractive and less effective in developing creative skills.

In this regard, the government has adopted a policy to implement the 2013 curriculum, at the beginning of the new semester of 2014, for all education units ranging from elementary to senior high school. One of the emphasis of the curriculum is a model approach called the Scientific approach, which consists of the Problem Based Learning approach, the Project Based Learning approach, and the Discovery Learning approach. Through these three approaches, it is hoped that it can develop the student creativity, concentration, and intelligence. Learning models that are assessed scientifically can help overcome the existing problems. Learning can develop students who actively learn about how to look for themselves (investigate themselves) so that the results obtained will last a long time in memory so that these students will not easily forget. Other studies suggest that a scientific approach is best for the present and future [10-12]. With a mindset that continues to be improved and developed, it can develop student intellectual and social aspects and the goal of a life-long healthy life can be realized [11]. Physical Education learning is believed to be able to develop student creativity, one of which is by using a problem-solving based learning model. The approach for learning can significantly increase the concentration of students at the end of the lesson, while the learning material does not affect the level of concentration. In order to increase student concentration, the teacher must plan learning well and choose the right learning approach by considering the allocation of learning time [13,14].

Each person has intelligence outwardly, but it will have a different effect on every aspect. In Physical Education learning that involves motoric aspects, it can provide learning experiences in the thinking process to solve kinaesthetic problems [15]. This is confirmed by other experts who state that intelligence is influenced by environmental factors [16-19], as an inborn trait [20-23], on the contrary, Multiple Intelligence theory states it as a combination of intelligence on inherited potential and skills that can be developed in various ways through relevant experiences [24]. Meanwhile, sensory factors and intelligence are influenced by an independent system, where the type and quality of information received by the sensory system determines a person intelligence [15]. Learning Physical Education in schools needs to be faced with improving the quality of life and preventing various diseases due to lack of movement, so that they can enjoy life properly and modestly [25]. Other researchers have also highlighted and identified the role of physical activity, physical fitness, and mental health of school age children and their implications for public health, which is an important factor in children lives [26,27].

The opinion above shows that physical fitness can determine the level of a person quality of life. If physical fitness is good, it can support student movement activities both in physical learning and in daily activities, so that they can enjoy life better. Physical Education programs should raise awareness, influence attitudes, and identify alternatives so that people can make the right choices and change behaviour to achieve optimal levels of physical and mental health [28]. Then, students who do regular exercise with a scientific approach at school and through awareness outside of school can improve the performance of their brains. They are expected to excel in school and be able to compete at the national and international levels.

\section{Methods}

This study used an experimental method, with a randomized control-group pretest-posttest design, because this study used a control and experimental group. The experimental group received Physical Education learning treatment with a scientific approach for 16 weeks with 3 meetings each week, while the control group received Physical Education learning treatment with a conventional approach for 16 weeks with 1 meeting each week. Before the two groups received the treatment, a creativity and physical fitness pretest was conducted first. After the two groups received the treatment, the posttest was carried out with the same test.

\section{Population and Sample}

The population in this study were students of Lembang Public Senior High School 1 who lived in mountainous areas. The sampling technique used simple random sampling. The sample in this study were 72 students who were divided into 2 classes, each class consisted of 36 people.

\section{Analysis}

Data analysis used SPSS version 22 with the following steps:

- Normality test used Kolmogorov-Smirnov on a pvalue $>0.05$. Homogeneity test used Levene's test at p-value $>0.05$.

- Analysis of hypotheses 1 to 4 used a paired sample t test, while hypotheses 5 to 6 used an independent $t$ test at $\mathrm{p}$-value $>0.05$.

\section{Results and Discussion}

The data served in Figure 1 shows that the experimental 
group with the Scientific approach in KBB Region creativity pretest result gained 14106 with an average of 391.83, while the posttest result was 15994 with an average of 444.28. The control group with the conventional approach in the KBB Region creativity pretest result gained 13867 with an average of 385.19, while the post-test was 13894 with an average of 385.94. As a comparator of creativity posttest results, the Bandung private group gained 10704 with an average of 356.80 .

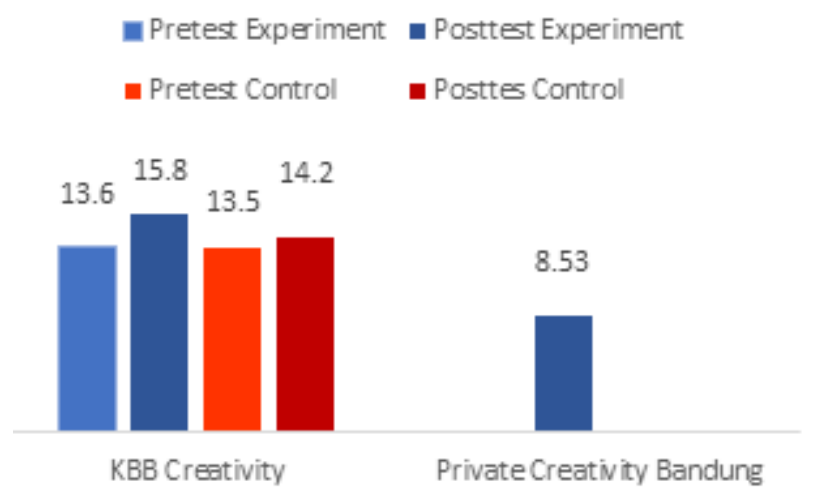

Figure 1. The Result Differences of Scientific and Conventional Approaches on Student Creativity in Mountainous Area

The data served in Figure 2 show that the experimental group with the Scientific approach in physical fitness pretest results gained 490 with an average of 13.61, while the posttest results were 568 with an average of 15.78 . The control group with the conventional approach in the Region KBB pretest results gained physical fitness 487 with an average of 13.53 , while the posttest was 512 with an average of 14.22. As the comparison result of the physical fitness posttest, Bandung private group gained 256 with an average of 8.53 .

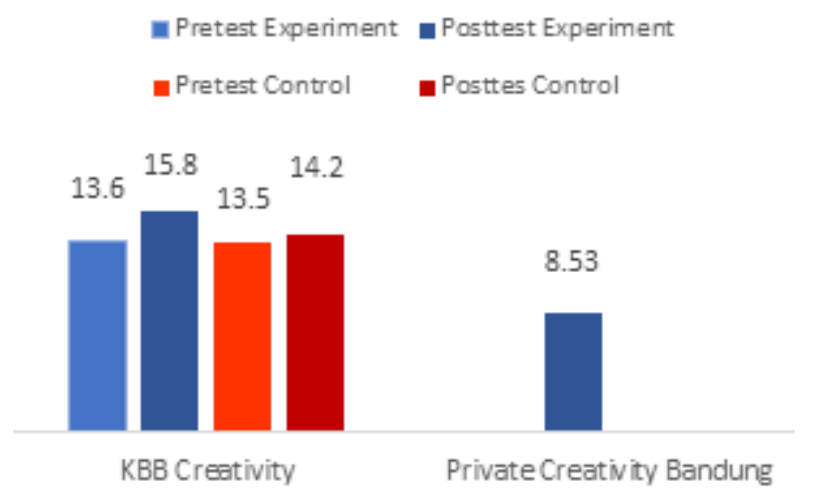

Figure 2. The Result Differences of Scientific and Conventional approaches on Student Physical Fitness in Mountainous Area

Based on table 1, the results of the paired sample test on the aspect of creativity obtained a significant value in the experimental group of $0.00<0.05$, which means that physical learning with a scientific approach had a significant effect on increasing student creativity in mountainous areas. Whereas in the control group, the significance value was $0.635>0.05$, which means that Physical Education learning with a conventional approach had no effect on increasing student creativity in mountainous areas.

Table 1. Results of Paired Test on Creativity

\begin{tabular}{ccc}
\hline Paired Sample t Test & T & $\begin{array}{c}\text { Sig. } \\
\text { (2-tailed) }\end{array}$ \\
\hline KR_Eks Pre KBB-KR_Eks Post KBB & -7.674 & 000 \\
\hline KR Kon Pre KBB-KR Kon Post KBB & -0.478 & 635 \\
\hline
\end{tabular}

Based on Table 2, the results of the paired sample test on the aspect of physical fitness, the significance value of the experimental group is $0.00<0.05$, which means that it has a significant effect on physical fitness, while the significant value in the control group is $0.049<0.05$, which means that it has a significant effect on physical fitness.

Table 2. Results of Paired Test on Physical Fitness

\begin{tabular}{ccc}
\hline Paired Sample t Test & T & $\begin{array}{c}\text { Sig. } \\
\text { (2-tailed) }\end{array}$ \\
\hline KJ_Eks Pre KBB - KJ Eks Post KBB & -12.315 & 000 \\
\hline KJ Kon Pre KBB-KJ Kon Post KBB & -2.043 & 049 \\
\hline
\end{tabular}

Based on Table 3, Physical Education learning with a scientific approach improved creativity and physical fitness for students in the mountainous area compared to Physical Education learning with a conventional method. Physical Education learning with a scientific approach is better than conventional approaches in increasing creativity and physical fitness student's in the mountainous area.

Table 3. Results of Independent Sample T Test

\begin{tabular}{ccc}
\hline Independent Sample t Test & T & Sig. (2-tailed) \\
\hline Creativity KBB & 7.373 & 000 \\
\hline Fitness KBB & 3.846 & 000 \\
\hline
\end{tabular}

\section{Discussion}

Based on the results of processing and analysis of existing data, it shows that Physical Education carried out in mountainous areas with a scientific approach affected increasing student's creativity and physical fitness. Physical Education Learning using a scientific approach is aimed to develop students learning through self-discovery activities by looking for information on their own so that the results obtained will last for a long time in memory. Through this method, students can also learn to analyze and try to solve the problems they face themselves to increase their creativity and physical fitness. Creative people are generally relatively healthy [29], both physically and mentally [30], and even easier to actualize themselves. Some physicians utilize self-actualization to be an indicator of mental health $[31,32]$. The opinions 
expressed describe that creative students are also students who have excellent physical fitness. It is in line with the results of research of Tarigan [33], which states that "Physical Education is carried out with the scientific approach to influence the improvement of student's creativity and physical fitness".

Although Physical Education conducted in mountainous areas with conventional approaches did not affect the increased creativity of students, it affected the improvement of student's physical fitness. Physical Education learning with a conventional approach can stimulate the student's critical thinking, creative thinking of teachers in presenting the lessons, and active participation of students during learning. The group with the technical approach alone (conventional learning) indicates the effect on creativity. However, it is still tiny compared to the group with the global-situational approach method (SG) or tactical approach model [34]. However, sometimes, it makes the teacher forget that the main component of learning in Physical Education is the physical fitness problem.

The results of research show that Physical Education carried out in the mountainous region with a more scientific approach influenced creativity and physical fitness compared to the conventional approach. New thought or idea falsifies previously thought or idea to solve a problem. Creativity is an ability possessed by every individual in creating something new $[35,36]$. Previous studies stated that Physical Education with a scientific approach had more effects on creativity, concentration, physical fitness, and intelligence of students compared to conventional approaches [33].

Physical Education and Sports in school should have a positive impact on students. It is advisable to use the FITT formula, which means: $\mathrm{F}=$ Frequency of exercise 3-5 times/week; I = intensity of light and moderate exercise with pulse zone (Target Heart Range) 50\% - 70\% X (220age); $\mathrm{T}=$ time to do sports activities, 30-60 minutes; $\mathrm{T}=$ the type of aerobic exercise performed [25].

From the research that had been conducted, it is known that there was a positive influence on the level of physical activity, physical fitness, and health-related quality of life [7,9,37-42]. Education is the key to helping change the direction of society for a better future. It is recommended that school leaders, policymakers, the university, and the school committee consider the ecological effect of maximizing the productivity and quality of teachers [43].

\section{Conclusion}

Physical Education in the mountainous region conducted with a scientific approach gave effects on the increased creativity and physical fitness of students. Physical Education in the mountainous areas conducted with conventional approaches did not affect the increased creativity of students, but it had an impact on the advanced physical fitness of students. Physical Education in the mountainous region conducted with a scientific approach gave better influence on the student's creativity and physical fitness compared to conventional approach.

\section{REFERENCES}

[1] Abduljabar B. Modul Pedagogi Olahraga. Bandung: FPOK UPI; 2011.

[2] Gu X, Solmon MA, Zhang T. Understanding middle school students' physical activity and health-related quality of life: An Expectancy-Value Perspective. Appl Res Qual Life 2014;9:1041-54.

[3] Beyer LE, Apple MW. The curriculum: Problems, politics, and possibilities. SUNY Press; 1998.

[4] Cook-Sather A, Clarke B, Condon D, Cushman K, Demetriou H, Easton L. Learning from the student's perspective: A sourcebook for effective teaching. Routledge; 2015.

[5] Grumet MR. Voice: The search for a feminist rhetoric for educational studies. Cambridge J Educ 1990;20:277-82.

[6] Kann L, Kinchen S, Shanklin SL, Flint KH, Hawkins J, Harris WA, et al. Youth risk behavior surveillanceUnited States, 2013. Morb Mortal Wkly Rep Surveill Summ 2014;63:1-168.

[7] Morales PF, Sánchez-López M, Moya-Martínez P, GarcíaPrieto JC, Martínez-Andrés M, García NL, et al. Healthrelated quality of life, obesity, and fitness in schoolchildren: the Cuenca study. Qual Life Res 2013;22:1515-23.

[8] Padilla-Moledo C, Castro-Pinero J, Ortega FB, Mora J, Márquez S, Sjöström $\mathrm{M}$, et al. Positive health, cardiorespiratory fitness and fatness in children and adolescents. Eur J Public Health 2012;22:52-6.

[9] Gu X, Chang M, Solmon MA. Physical Activity, Physical Fitness, and Health-Related Quality of Life in SchoolAged Children 2016:117-26.

[10] Zeigler EF. Application of a Scientific Ethics Approach to Sport Decisions. Quest 1980;32:8-21.

[11] Bacanak A, Gökdere M. Investigating level of the scientific literacy of primary school teacher candidates. Asia-Pacific Forum Sci. Learn. Teach., vol. 10, 2009.

[12] Hurd PD. Scientific literacy: New minds for a changing world. Sci Educ 1998;82:407-16.

[13] Raviv S, Low M. Influence of physical activity on concentration among junior high-school students. Percept Mot Skills 1990;70:67-74.

[14] Dorfmann. The Influence of Various Physical Activities on Concentncion by High School Students. Tel-Aviv University, 1988.

[15] Gardner HE. Multiple intelligences: New horizons in theory and practice. Basic books; 2008.

[16] Diamond M, Hopson J. Magic trees of the mind: how to 
nuture your child's intelligence, creativity, and healthy emotions from birth through adolescence. Penguin; 1999.

[17] Lucas A, Morley R, Cole TJ. Randomised trial of early diet in preterm babies and later intelligence quotient. Bmj 1998;317:1481-7.

[18] Neisser U, Boodoo G, Bouchard Jr TJ, Boykin AW, Brody $\mathrm{N}$, Ceci SJ, et al. Intelligence: knowns and unknowns. Am Psychol 1996;51:77.

[19] Nisbett RE. Intelligence and how to get it: Why schools and cultures count. WW Norton \& Company; 2009.

[20] Eysenck HJ, Eysenck SBG. Manual of the Eysenck personality questionnaire: (EPQ-R Adult). EdITS/Educatio nal and Industrial Testing Service; 1994.

[21] Herrnstein RJ, Murray C. The bell curve: Intelligence and class structure in American life. Simon and Schuster; 2010.

[22] Jensen AR. Bias in mental testing 1980.

[23] Jensen AR. The g factor: The science of mental ability. vol. 648. Praeger Westport, CT; 1998.

[24] Gardner HE. Frames of mind: The theory of multiple intelligences. Hachette Uk; 2011.

[25] Tarigan B. Optimalisasi Pendidikan Jasmani dan Olahraga Berlandaskan Ilmu Faal Olahraga. Bandung FPOK UPI 2009.

[26] Blair S, Cheng Y, Holder JS. Is physical activity or physical fitness more important in defining health benefits? Med Sci Sports Exerc 2001;33

[27] Fogelholm M. Physical activity, fitness and fatness: relations to mortality, morbidity and disease risk factors. A systematic review. Obes Rev 2010;11:202-21.

[28] Misner JE. Are we fit to educate about fitness? J Phys Educ Recreat Danc 1984;55:26-40.

[29] Runco MA, Albert RS. Creativity research: A historical view. Cambridge University Press; 2010.

[30] Runco MA, Charles R. Developmental trends in creativity. Creat Res Handb 1997;1:113-50.

[31] Maslow AH. The farther reaches of human nature. vol. 19711. Viking Press New York; 1971.

[32] Rogers CR. Toward a theory of creativity. ETC A Rev Gen Semant 1954:249-60.
[33] Tarigan B. Pengaruh Pendekatan Saintifik Dalam Pembelajaran Pendidikan Jasmani Dan Olahraga Terhadap Kreativitas, Konsentrasi, Kebugaran Jasmani Dan Kecerdasan Spasial (Spatial Inttelegence) Pada Siswa Sekolah Dasar. Bandung: 2015.

[34] Morales JCP, Greco PJ, Andrade RL. A description of the teaching-learning processes in basketball and their effects on tactical procedural knowledge. Rev Psicol Del Deport 2009; 18:469-73.

[35] Solehuddin M. Sustainable Counselling Values by Indonesian Preschool Teachers to Prepare More Tolerant Young Global Citizens. JOMSIGN J Multicult Stud Guid Couns 2019;3:119-36.

[36] Munandar U. Pengembangan Kreativitas Anak Berbakat Jakarta: PT Rineka Cipta; 2012.

[37] Bize R, Johnson JA, Plotnikoff RC. Physical activity level and health-related quality of life in the general adult population: a systematic review. Prev Med (Baltim) 2007;45:401-15.

[38] Brovold T, Skelton DA, Sylliaas H, Mowe M, Bergland A. Association between health-related quality of life, physical fitness, and physical activity in older adults recently discharged from hospital. J Aging Phys Act 2014;22:40513 .

[39] Dalton III WT, Schetzina KE, Pfortmiller DT, Slawson DL, Frye WS. Health behaviors and health-related quality of life among middle school children in Southern Appalachia: data from the winning with wellness project. J Pediatr Psychol 2011;36:677-86.

[40] Fedewa AL, Ahn S. The effects of physical activity and physical fitness on children's achievement and cognitive outcomes: a meta-analysis. Res Q Exerc Sport 2011;82:521-35

[41] Hebestreit H, Schmid K, Kieser S, Junge S, Ballmann M, Roth K, et al. Quality of life is associated with physical activity and fitness in cystic fibrosis. BMC Pulm Med 2014;14:26.

[42] E. Dyment J, Hill A, Emery S. Sustainability as a crosscurricular priority in the Australian curriculum: A Tasmanian investigation. Environ Educ Res 2015;21:1105-26.

[43] Price D, McCallum F. Ecological influences on teachers' well-being and "fitness." Asia-Pacific J Teach Educ 2015;43:195-209 